九州大学学術情報リポジトリ

Kyushu University Institutional Repository

\title{
Flow Pattern of Two-phase Flow Boiling with Heat Transfer and Pressure Drop Using Natural Refrigerant (Propane) in Microchannel
}

\section{A. S. Pamitran}

Department of Mechanical Engineering, Faculty of Engineering, Unversitas Indonesia

\section{S. Novianto}

Department of Mechanical Engineering, Faculty of Industrial Technology, Universitas Trisakti

N. Mohd-Ghazali

Faculty of Mechanical Engineering, Universiti Teknologi Malaysia

R. A Koestoer

Department of Mechanical Engineering, Faculty of Engineering, Unversitas Indonesia

https://doi.org/10.5109/4150474

出版情報：Evergreen. 7 (4)，pp.544-548，2020-12. 九州大学グリーンテクノロジー研究教育センター バージョン：

権利関係 : 


\title{
Flow Pattern of Two-phase Flow Boiling with Heat Transfer and Pressure Drop Using Natural Refrigerant (Propane) in Microchannel
}

\author{
A.S. Pamitran ${ }^{1, *}$, S. Novianto ${ }^{2}$, N. Mohd-Ghazali ${ }^{3}$, R.A Koestoer ${ }^{1}$ \\ ${ }^{1}$ Department of Mechanical Engineering, Faculty of Engineering, Unversitas Indonesia, Indonesia \\ ${ }^{2}$ Department of Mechanical Engineering, Faculty of Industrial Technology, Universitas Trisakti, Indonesia \\ ${ }^{3}$ Faculty of Mechanical Engineering, Universiti Teknologi Malaysia, Skudai, Johor Bahru 81310, Malaysia
}

*Author to whom correspondence should be addressed:

E-mail: pamitran@eng.ui.ac.id

(Received November 4, 2020; Revised December 9, 2020; accepted December 16, 2020).

\begin{abstract}
Natural refrigerant as replacement for conventional refrigerant is more intensively used for reducing environmental damage. This research aims were to flow pattern mapping and study heat transfer, pressure drop of two-phase flow boiling with natural refrigerant in microchannel. Experimental method used evaporative process in test section on tube diameter $500 \mu \mathrm{m}$ and length 0.5 meter. Observation parameter used mass flux $681-766 \mathrm{kgm}^{-2} \mathrm{~s}^{-1}$, heat flux $5.28-7.66 \mathrm{kWm}^{-2}$ and saturation temperature $31.96-33.14{ }^{\circ} \mathrm{C}$. Result experiment showed single flow regime and two-phase flow regime with low vapor quality to 0.15 . Frictional pressure drop was higher than acceleration pressure drop, where the resulting acceleration pressure drop has been calculated with small value from total pressure drop (0.5\%). Mass flux contributed a strong effect on coefficient of heat transfer convective. Heat flux more effected to heat transfer of two-phase flow nucleate boiling. Wang map were used to plot flow patterns of two-phase in microchannel.
\end{abstract}

Keywords: flow pattern; two-phase; pressure drop; heat transfer; microchannel

\section{Introduction and background}

Most of conventional refrigerant has effect to damage of environmental. Natural refrigerant as replacement for conventional refrigerant is more intensively used for reduce environmental damage. Propane as natural refrigerant with zero ODP and small effect (less than 4) of global warming potential ${ }^{1}$. Friendly refrigerant need in industrial became focus of manufacturer for looking for hydrocarbon refrigerant as the alternative refrigerant for household refrigerant ${ }^{2)}$.

Previous studies about classification of microchannel have been done some author. ${ }^{3)}$ defined that the microchannel based on confinement number ia more than 0.5. ${ }^{4)}$ classified microchannel by using a convective confinement number as function of the Bo-number and the Re-number. The channel is to be as a microchannel when a convective confinement number less value of 160 . A commonly used criterion was arranged by ${ }^{5}$, who defined the microchannel was between $200 \mu \mathrm{m}$ to $10 \mu \mathrm{m}$, and the minichannels was between $3 \mathrm{~mm}$ to $200 \mu \mathrm{m}$.

Pressure drop analysis in microchannel became importance to study. Pressure drop higher on microchannel results highly power consumption on the system. Pressure drop prediction on two-phase flow boiling can be predicted with homogenous models. The homogeneous models are in the following assumption: equal vapor and liquids velocity, thermodynamic balance attainment between vapor and liquid phases. The homogeneous models use friction factor of single phase for two-phase flow ${ }^{6}$.

Two-phase flow heat transfer in microchannel is better than macrochannel. It's caused surface area of heat transfer per flow rate which is higher on microchannel. Prediction method with super position models determined by convective heat transfer and nucleate boiling heat transfer. ${ }^{7}$ have proposed a new correlation of boiling heat transfer coefficient based on the superposition model on small tube.

${ }^{8)}$ reported that boiling heat transfered coefficient on low mass quality. The equation of nucleate boiling heat transfer is predicted by ${ }^{9-10)}$. The result of experiment shows that the values of nucleate boiling heat transfer with the Cooper model is lower than the Gorenflo's model.

Flow pattern of two-phase flow in microchannel is limited in a few publication. A flow pattern map is currently the most useful tool to predict the flow regime at the given condition. Flow pattern map has been developed by ${ }^{11)}$ for air-water and oil-water. Superficial velocity of liquid and vapor are used to map drawing. ${ }^{12)}$ 
made map of flow pattern on horizontal flow. After that 13) modified the flow pattern map.

14) has modified Baker map to plotting his experiment. The experimental working on fluids used R-22, R-134a and R-407C in macrochannel with $6.5 \mathrm{~mm}$ inner diameter. The flow patterns were depended by mass velocities, where mass velocities were in part of two-phase multipliers function. The flow pattern regime consisted of wavy, annular, stratified and intermittent.

One of the research obstacle for the next experiment are optimization of two-phase flow in microchannel to minimize pressure drop and or maximize heat transfer. ${ }^{15)}$ has investigated entropy generation minimization of twophase flow of ammonia, R-22 and R-134a in pipe with inner diameter of $3 \mathrm{~mm}$. One of the result in investigation is that heat transfer coefficient increases when mass flux raises. Ammonia has higher heat transfer coefficient than refrigerant R-22 and R-134a.

The aim was in mapping of flow pattern and to study heat transfer and pressure drop of two-phase flow boiling on microchannel at low vapor mass quality. Result of experiment can help in predicting of heat transfer and pressure drop design on heat exchanger design.

\section{Method and experimental setup}

The experiment was conducted in a research laboratory of air conditioning and refrigeration. Fig. 1 showed the experimental apparatus. In the red line boundary, there were the test section which used SS 316 pipe with $0.5 \mathrm{~mm}$ diameter and 0.5 meters in length. Heat was generated on the pipe by an electrical heater equipment. The refrigerant (R-290) entered the pipe as liquid phase and came out from the pipe as liquid-vapor flow. The thermocouples were contacted at the surface of the pipe.

There were five parts of thermocouples along the pipe, with the equal distance between each thermocouple. In each parts, there were two thermocouples at the upper and bottom of the pipe.

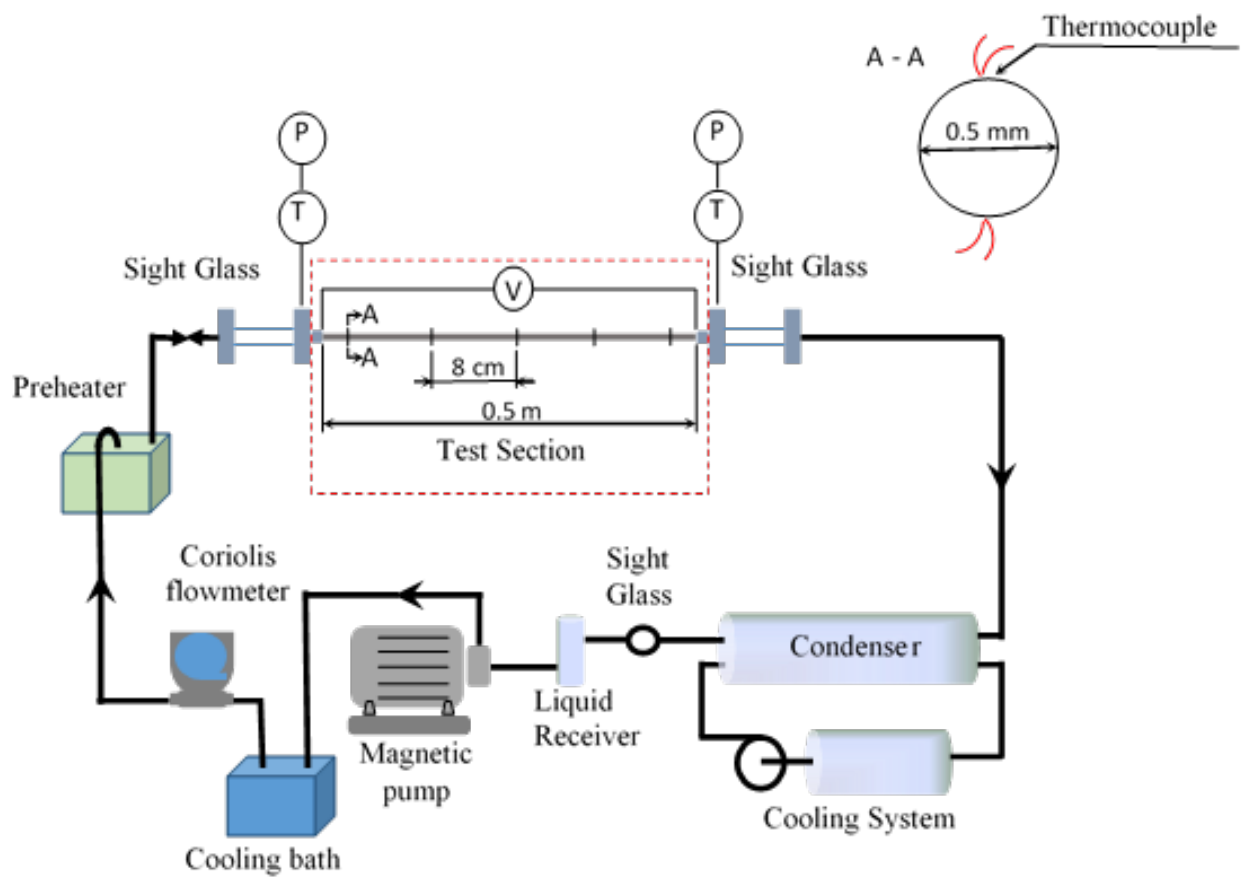

Fig. 1: Experimental apparatus.

The immersed thermocouples was inserted at inlet and outlet to measure the temperature difference. The pressure transmitters were located at inlet and outlet of the test section pipe for measuring a pressure difference of working fluid (refrigerant). The cooling system (3 hp) was installed on condenser to condense working fluid that left the test section. Refrigerant in the liquid phase was moved and circulated using a magnetic pump. The cooling bath that used to maintain the working fluid low temperature was located after a magnetic pump.

The Coriolis as mass flow meter was used to measure the flow rate of the refrigerant. The preheater was placed before the inlet of the test section for conditioning of refrigerant temperature. Phase of working fluids was observed by sight glass. The test section was located between the sight glass.

The uncertainty of experiment showed on table 1 .

Table 1. Uncertainty experiment

\begin{tabular}{ll}
\hline Measurement & Uncertainty \\
\hline Average temperature & $\pm 0.42{ }^{\circ} \mathrm{C}$ \\
Heat received from heater & \pm 0.05 Watt \\
Mass flow of refrigerant & $\pm 0.05 \%$ \\
\hline
\end{tabular}




\section{Data Reduction}

Flow boiling pressure drop experiment has been measured by deferential pressure drop transmitters. Flow boiling pressure drop in pipe could be occurred at three regimes. So, pressure drop regime could be calculated as sum of liquid single phase pressure drop, two-phase pressure drop and vapor single phase pressure drop. This pressure drop experiment occurred on liquid single phase pressure drop and two-phase pressure drop. It caused mass quality of experiment less than 0.15 . The length of liquid single phase pressure drop could be determined by length of sub-cooled. Eq. 1 give length of sub-cooled equation. The equation was written as follow:

$$
Z_{s c}=L \frac{i_{f}-i_{f i}}{\Delta i}
$$

Eq. 2 give the basic of pressure drop. The equation was written as follow ${ }^{6)}$ :

$$
\Delta P_{\text {tot }}=\Delta P_{\text {fric }}+\Delta P_{\text {acc }}+\Delta P_{s t}
$$

Eq. 3 give the friction two-phase pressure drop equation with homogeneous model. The equation was written as follow:

$$
\Delta P_{f r i c}=\frac{2 f_{t p} G^{2} v_{f}\left(L-z_{s c}\right)}{D}\left[1+\frac{v_{f g}}{v_{f}}\left(\frac{x_{o}}{2}\right)\right]
$$

Eq. 4 give the two-phase flow friction factor equation may be expressed in terms of the Reynolds number by the Blasius equation:

$$
f_{t p}=\frac{0.079}{[G D / \bar{\mu}]^{0.25}}
$$

Eq. 5 give the average viscosity equation of twophase from ${ }^{16)}$. The equation was written as follow:

$$
\bar{\mu}=\left[\frac{x}{\mu_{g}}+\frac{(1-x)}{\mu_{l}}\right]^{-1}
$$

Eq. 6 give the acceleration two-phase pressure drop equation with homogeneous model. The equation was written as follow:

$$
\Delta P_{a c c}=G^{2} \vartheta_{f g} x_{o}
$$

Eq. 7 give the equation of local heat transfer coefficient experiment of two-phase flow. The equation was written as follow:

$$
h=\frac{\ddot{q}}{T_{\text {wall }}-T_{\text {sat }}}
$$

Plotting data experiment at Wang map used non dimensional parameter. Eq. 8 and 9 were non dimensional parameter as written as follow:

$$
\lambda=\left(\frac{\rho_{g} \rho_{l}}{\rho_{a} \rho_{w}}\right)^{1 / 2}
$$

$$
\psi^{\prime}=\left(\frac{\sigma_{w}}{\sigma}\right)^{1 / 4}\left(\left(\frac{\mu_{l}}{\mu_{w}}\right)\left(\frac{\rho_{w}}{\rho_{l}}\right)^{2}\right)^{1 / 3}
$$

\section{Result and Discussion}

Experiment pressure drop in test section occurred on single phase regime and two-phase regime. The average of initial of two-phase flow regime was described on the end of sub-cooled length that occurred at $17 \mathrm{~mm}$.

Pressure drop on single phase regime was lower than pressure drop at two-phase regime. Two-phase pressure drop in horizontal tube consisted of frictional and acceleration pressure drop component. The static pressure drop equaled to zero, where the experimental test section was on the horizontal axis. Pressure drop friction on single phase regime was lower than pressure drop friction on two-phase regime.

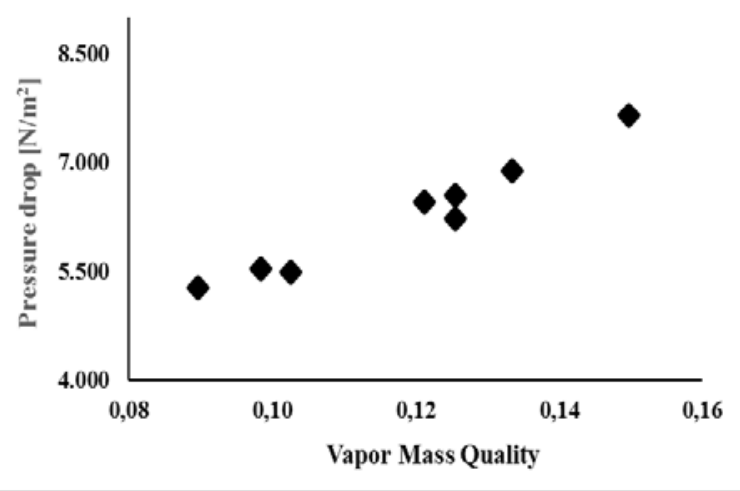

Fig. 2: Effect of vapor mass quality on pressure drop.

Pressure drop acceleration on single phase regime was lower than acceleration pressure drop on two-phase regime. Total acceleration pressure drop experiment had been calculated with result $0.5 \%$ of total pressure drop. Fig. 2 showed effect of mass vapor quality on pressure drop in microchannel. Increasing of mass quality caused increasing of pressure drop. Experimental data showed pressure drop prediction was higher than experiment pressure drop.

17) clearly explained with using experiment display of frictional pressure drop with vapor mass quality raise. The pressure drop of vapor phase often dominates the total frictional pressure drop of two-phase. With the raise of mass vapor quality, produce of vapor phase flow is large in the tube which lead to higher frictional pressure drop of two-phase.

Coefficient of heat transfer mechanism of two-phase flow has been calculated by super position model. Coefficient of heat transfer is sum of convective/single phase heat transfer and nucleate boiling heat transfer. This experiment used heat transfer prediction of single phase from ${ }^{18)}$ correlation. The correlation has been made based on ${ }^{19)}$ correlation and has mean relative deviation $7 \%$ with ${ }^{20)}$ correlation. Nucleate boiling heat transfer prediction used ${ }^{9)}$ correlation.

Increasing heat flux to test section caused mass quality increase. Outlet mass quality of experiment reach to low 
quality 0.15 . The experiment result showed effect of heat flux on coefficient of heat transfer. Higher heat flux caused higher coefficient of heat transfer at the low quality. Data experimental showed prediction of nucleate heat transfer higher than prediction of single heat transfer.

21) has experiment with $1 \mathrm{~mm}$ diameter tube and R134a. They reported that higher heat flux will effect to higher coefficient of heat transfer. ${ }^{22)}$ reported that the increase of heat flux has significant effect on enhancing nucleate boiling heat transfer. ${ }^{23)}$ has experimented flow boiling in hydraulic diameter $0.46 \mathrm{~mm}$. The experiment result explained the highest value of the local heat transfer coefficient of two-phase occurred at vapor quality slightly above zero. This could be due to the evaporation in the liquid micro-layer underneath the nucleating bubble.

Flow pattern map at present experiment used ${ }^{14)}$ map. The regime flow pattern consisted of stratified, stratified wavy, intermittent and annular. The Wang map was used in macrochannel commonly. In this research, the result of observation of flow pattern from sight glass experiment was compared with regime on Wang map. Plotting experimental data at the map showed on Fig. 3, where all data has plotted on intermittent flow pattern regime. The comparison of visualisation in sight glass with Wang map showed the same flow pattern. The figure below has been referred on the conference of quality in research ${ }^{24)}$.

25) found data experiment from their research by inner diameter $0.8 \mathrm{~mm}$ with $\mathrm{CO}_{2}$ as working fluids. The observations in microchannel flow showed a dominance of intermitent and annular flow regimes. The transitions beetwen intermittent, annular and droplet flow regimes were not predicted well.

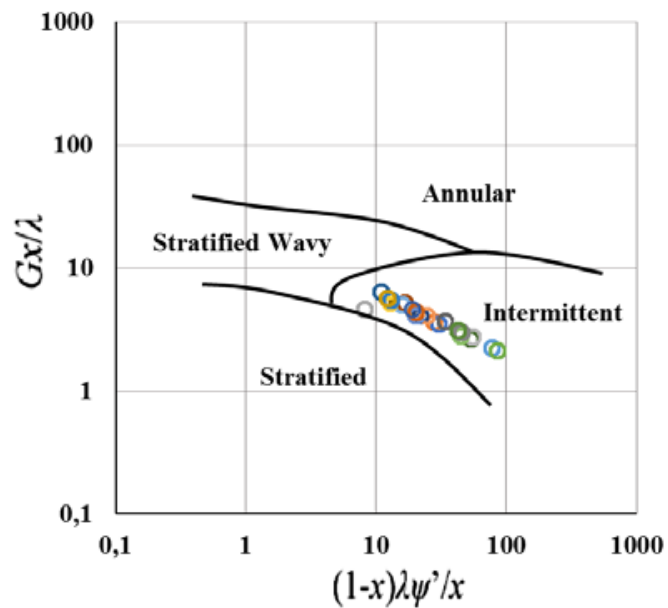

Fig. 3: Plotting experimental data at the Wang map.

\section{Conclusion}

Study of flow pattern of two-phase with low vapor mass quality in microchannel has been conducted completely. The conclusion of research are as follows:

- Pressure drop on two-phase flow through in microchannel was effected by mass quality, where increasing of mass quality caused increasing of pressure drop. The frictional pressure drop was higher than acceleration pressure drop.

- Coefficient of heat transfer of two-phase flow in microchannel was effected by heat flux, where increasing of heat flux caused increasing of heat transfer coefficient on the low mass quality.

- Flow pattern prediction of two-phase on the low mass quality in microchannel by ${ }^{11)}$ map resulted the intermittent flow pattern.

\section{Acknowledgement}

This research is funded by International Research Collaboration Grant based on LoA number NKB1951/UN2.R3.1/HKP.05.00/2019

\section{Nomenclature}

\begin{tabular}{|c|c|}
\hline$D$ & tube diameter $(\mathrm{m})$ \\
\hline$G$ & mass flux $\left(\mathrm{kgm}^{-2} \mathrm{~s}^{-1}\right)$ \\
\hline$h$ & heat transfer coefficient $\left(\mathrm{Wm}^{-2} \cdot{ }^{\circ} \mathrm{C}^{-1}\right)$ \\
\hline$L$ & tube length $(\mathrm{m})$ \\
\hline$i_{f}$ & saturated enthalpy $(\mathrm{kJ} / \mathrm{kg})$ \\
\hline$i_{f i}$ & enthalpy at the inlet $(\mathrm{kJ} / \mathrm{kg})$ \\
\hline$\Delta i$ & increasing of enthalpy ( $\mathrm{kJ} / \mathrm{kg})$ \\
\hline$\ddot{q}$ & heat flux $\left(\mathrm{Wm}^{-2}\right)$ \\
\hline$T_{\text {wall }}$ & wall temperature $\left({ }^{\circ} \mathrm{C}\right)$ \\
\hline$T_{s} \underline{a t}$ & saturation temperature $\left({ }^{\circ} \mathrm{C}\right)$ \\
\hline$x_{0}$ & out let mass vapor quality $(-)$ \\
\hline$Z_{s} \underline{c}$ & sub-cooled length $(\mathrm{m})$ \\
\hline$\Delta P_{t o t}$ & total pressure drop \\
\hline$\Delta P_{\text {fric }}$ & friction pressure drop \\
\hline$\Delta P_{a} \underline{c} \underline{c}$ & acceleration pressure drop \\
\hline$\Delta P_{s t}$ & static pressure drop \\
\hline
\end{tabular}

Greek symbols

\begin{tabular}{|c|c|}
\hline$\rho_{g}$ & vapor density of refrigerant $\left(\mathrm{kgm}^{-3}\right)$ \\
\hline$\rho_{l}$ & liquid density of refrigerant $\left(\mathrm{kgm}^{-3}\right)$ \\
\hline$\rho_{a}$ & density of air $\left(\mathrm{kgm}^{-3}\right)$ \\
\hline$\rho_{\underline{w}}$ & water density $\left(\mathrm{kgm}^{-3}\right)$ \\
\hline$\mu_{l}$ & liquid viscosity of refrigerant (Pa.s) \\
\hline$\mu_{g}$ & gas viscosity of refrigerant (Pa.s) \\
\hline$\mu_{\underline{w}}$ & water viscosity (Pa.s) \\
\hline $\bar{\mu}$ & mean two-phase viscosity (Pa.s) \\
\hline$\sigma$ & surface tension $\left(\mathrm{Nm}^{-1}\right)$ \\
\hline$\sigma_{\underline{w}}$ & water surface tension $\left(\mathrm{Nm}^{-1}\right)$ \\
\hline$f_{t} \underline{p}$ & Friction factor of two-phase \\
\hline$v_{f}$ & liquid specific volume $\left(\mathrm{m}^{3} \mathrm{~kg}^{-1}\right)$ \\
\hline$v_{f g}$ & $\begin{array}{l}\text { difference in specific volumes of } \\
\text { saturated liquid and vapor }\left(\mathrm{m}^{3} \mathrm{~kg}^{-1}\right)\end{array}$ \\
\hline
\end{tabular}

\section{References}

1) K.I. Choi, A.S. Pamitran, J.T. Oh, and K. Saito, "Pressure drop and heat transfer during two-phase flow vaporization of propane in horizontal smooth 
minichannels," International Journal of Refrigeration., 32, 837-845 (2009).

2) M.I. Alhamid, N.Nasruddin, Budihardjo, E. Susanto, T.F. Vickary, M.A. Budiyanto, "Refrigeration Cycle Exergy-Based Analysis of Hydrocarbon (R600a) Refrigerant for Optimization of Household Refrigerator," Evergreen, Joint Journal of Novel Carbon Resource Sciences \& Green Asia Strategy, 06, 01, 71-77 (2019).

3) P.A. Kew, and K. Cornwell, "Correlations for the Prediction of Boiling Heat Transfer in SmallDiameter Channels,” Appl. Therm. Eng, 17, 8-10, 705-715 (1997).

4) T. Harirchian, and S.V. Garimella, “A Comprehensive Flow Regime Map for Microchannel Flow Boiling With Quantitative Transition Criteria,” Int. J. Heat Mass Transfer, 53, 13-14, 2694-2702 (2010).

5) S.G. Kandlikar, and W.J. Grande, "Evolution of Microchannel Flow Passages - Thermohydraulic Performance and Fabrication Technology," Heat Transfer Eng, 24, 1, 3-17 (2003).

6) J.G. Collier, and J.R. Thome, "Convective boiling and condensation,” Clarendon Press, 1994.

7) K.I. Choi, and J.T. Oh, “Two-phase flow boiling heat transfer of R-410A and R-134A in horizontal small tubes,” Int. J. of Technology, 2, 139-146 (2011).

8) H. Li, and P. Hrnjak, "Heat transfer coefficient, pressure drop, and flow patterns of R1234ze (E) evaporating in microchannel tube," International Journal of Heat and Mass Transfer, 138, 1368-1386 (2019).

9) M. Cooper, "Heat flow rates in saturated nucleate pool boiling-a wide-ranging examination using reduced properties," Advances in heat transfer. Elsevier. 1984.

10) D. Gorenflo, D. K. in: VDI Heat Atlas, second ed. Springer, 757-787 (2010).

11) O. Baker, "Design of pipelines for the simultaneous flow of oil and gas," Fall Meeting of the Petroleum Branch of AIME, Society of Petroleum Engineers, 1953.

12) Y. Taitel, and A.E. Dukler, “A model for predicting flow regime transitions in horizontal and near horizontal gas-liquid flow," AIChE journal, 22, 4755 (1976).

13) D. Steiner, "Heat transfer to boiling saturated liquids," VDI-Warmeatlas (VDI Heat Atlas), 1993.

14) C.C. Wang, C.S. Chiang, and D.C. Lu, "Visual observation of two-phase flow pattern of R-22, R134a, and R-407C in a 6.5-mm smooth tube," Experimental thermal and fluid science, 15, 395-405 (1997).

15) A.S. Syahrul, M.G. Normah, J.T. Oh, A. Robiah, and M.Y. Yushazaziah, "Entropy Generation Minimization of Two-Phase Flow in a Mini Channel with Genetic Algorithm,” Evergreen, Joint Journal of Novel Carbon Resource Sciences \& Green Asia Strategy, 06, 01, 39-43 (2019).

16) W. Mcadams, "Vaporization inside horizontal tubesII, Benzene oil mixtures,” Trans. ASME, 64, 193-200 (1942).

17) Z. Yang, M. Gong, G. Chen, X. Zou, and J. Shen, "Two-phase flow patterns, heat transfer and pressure drop characteristics of R600a during flow boiling inside a horizontal tube," Applied Thermal Engineering, 120, 654-671 (2017).

18) R.A. Koestoer, S. Novianto, and A.S. Pamitran, "Heat transfer of single phase flow with natural refrigerant (R-290) in microchannel,” AIP Conference Proceedings, AIP Publishing, 020058, 2019.

19) F. Dittus, and L. Boeltoer, University of California publications on engineering. University of California publications in Engineering, 2, 371 (1930).

20) B. Wang, and X. Peng, "Experimental investigation on liquid forced-convection heat transfer through microchannels," International Journal of Heat and Mass Transfer, 37, 73-82 (1994).

21) S. Saisorn, P. Wongpromma, and S. Wongwises, "The difference in flow pattern, heat transfer and pressure drop characteristics of mini-channel flow boiling in horizontal and vertical orientations," International Journal of Multiphase Flow, 101, 97112 (2018).

22) Z. Liang, J. Linlin, L. Jianhua, and Z. Yue, "Investigation of flow boiling heat transfer characteristics of CO2in horizontal mini-tube," International Journal of Thermal Sciences, 138, 109-115 (2019).

23) A.H. Al-Zaidi, M.M. Mahmoud, and T.G. Karayiannis, "Flow boiling of HFE-7100 in microchannels: Experimental study and comparison with correlations," International Journal of Heat and Mass Transfer, 140, 100-128 (2019).

24) A.S. Pamitran, S. Novianto, and S.A. Santoso, "Intermittent Flow Pattern on Two Phase Flow Boiling with Horizontal Microchannel,” Evergreen, Joint Journal of Novel Carbon Resource Sciences \& Green Asia Strategy, 07, 01, 150-154 (2020).

25) J. Pettersen,’Two-phase flow pattern, heat transfer, and pressure drop in microchannel vaporization of $\mathrm{CO}_{2}$," ProQuest Science Journals Ashrae Transactions, 109, 2003. 